\title{
MENINGKATKAN AKTIVITAS DAN PRESTASI BELAJAR IPS SISWA KELAS IV SD NEGERI 18 KENDARI MELALUI MODEL PEMBELAJARAN KOOPERATIF TIPE STAD ${ }^{1}$

\author{
MPROVING ACTIVITIES AND ACHIEVEMENTS OF IPS STUDENTS IN CLASS IV SD \\ NEGERI 18 KENDARI THROUGH LEARNING MODELS STOP TYPE COOPERATIVE \\ Sultan2 \\ email: sultan210@gmail.com
}

\author{
${ }^{1)}$ Hasil Penelitian Tahun 2019, ${ }^{2)}$ Guru SD Negeri 18 Kendari
}

\begin{abstract}
ABSTRAK : Penilaian ini berisi proses pembelajaran IPS pada siswa kelas VI yang dilakukan di SD Negeri 18 Kendari. Tujuan dan karya tulis ini, adalah membuktikanbahwa kegiatan bermain dan membuat display dapat memberikan keberhasilan pada proses pembelajaran siswa dalam rangka pencapaian mastery learning. Dalam penelitian ini penulis melibatkan 12 siswa kelas VI yang ada di SD Negeri 18 Kendari yaitu siswa kelas VI untuk tahun pelajaran 2014/2015. Alat penilaian yang digunakan berbentuk tes dan non tes. Penelitian ini dilaksanakan dalam tiga siklus. Antara lain siklus I, siklus II dan siklus III merupakan rangkaian kegiatan yang saling berkaitan. Faktor yang diteliti dalam penelitian ini adalah proses pembelajaran siswa yakni mengamati kelancaran pembelajaran, suasana dan aktivitas pembelajaran serta hasil belajar siswa. Rubrik penilaian dilakukan pada saat siswa terlibat dalam kegiatan kelompok ketiga membuat display dan melakukan permainan. Rubrik bertujuan untuk melihat keterampilan-keterampilan yang diharapkan pada paradigma pembelajaran dalam pedoman KTSP yaitu,1) learning to know, 2) Learning to do, 3) leraning to be, dan 4) learning to live togather telah dicapai oleh siswa. Perbandingan hasil pre-test, siklus I, siklus II, dan siklus III, serta rubrik penilaian saat pembuatan display dan permainan menunjukan bahwa keterampilan yang diharapkan dari setiap kriteria penilaian dapat dilalui dengan nilai yang baik oleh semua kelompok. Meskipun penilaian rubrik dilakukan dalam kelompok, namun keterampilan itu tetap menjadi tanggung jawab setiap individu siswa. Hal penelitian ini menunjukan bahwa penerapan tehnik permainan dan display dapat meningkatkan hasil belajar IPS karena suasana belajar dirasakan menyenangkan dan siswa lebih aktif menyelesaikan tugas serta terjadi peningkatan prestasi belajar.
\end{abstract}

Kata Kunci: Aktivitas, Prestasi Belajar, STAD

ABSTRACT: This assessment contains the social studies learning process for grade VI students conducted at SD Negeri 18 Kendari. The purpose and this paper, is to prove that playing activities and making displays can provide success in the learning process of students in order to achieve mastery learning. In this study the authors involved 12 grade VI students in 18 Public Elementary School Kendari, namely grade VI students for the 2014/2015 school year. Assessment tools used in the form of tests and non-tests. This research was conducted in three cycles. Among other cycles I, cycle II and cycle III is a series of interrelated activities. The factors examined in this study were the students' learning processes, namely observing the smooth learning, the atmosphere and learning activities and student learning outcomes. The assessment rubric is done when students are involved in third group activities making displays and playing games. The rubric aims to look at the skills expected in the learning paradigm in the SBC guidelines, namely, 1) learning to know, 2) learning to do, 3) learning to be, and 4) learning to live togather has been achieved by students. Comparison of pre-test results, cycle I, cycle II, and cycle III, as well as the assessment rubric when making displays and games shows that the skills expected from each assessment criteria can be passed with good grades by all groups. Although the rubric assessment is done in groups, the skill remains the responsibility of each individual student. This study shows that the application of game and display techniques can improve social studies learning outcomes because the learning atmosphere is felt to be fun and students are more active in completing assignments and there is an increase in learning achievement. 


\section{PENDAHULUAN}

Guru merupakan salah satu faktor penentu keberhasilan setiap usaha perbaikan pendidikan. Untuk itu setiap pembaharuan pendidikan, selalu bermuara pada faktor guru. Hal ini menunjukkan betapa besar peran guru dalam dunia pendidikan. Guru dituntut memiliki multi peran, yakni mampu menciptakan kondisi belajar mengajar yang efektif. Guru harus dapat memberikan kesempatan belajar bagi siswa, dan mapu meningkatkan kualitas peran siswa. Siswa jangan dianggap sebagai obyek yang secara pasif menerima informasi dari gur, tetapi lebih dari itu, siswa dianggap sebagai subyek yang berperan secara aktif dalambelajar. Guru harus mampu membelajarkan ke siswa bagaimana siswa dapat belajar dari perilaku dirinya atau dari lingkungan. Guru harus dapat merancang model pembelajarn yang cocok untuk setiap pertemuan dalam setiap materi pelajaran. Kesempatan siswa belajar dari perilaku dirinya atau dari lingkungannya perlu ditingkatkan,dengan cara melibatkan siswa secara aktif dalam proses pembelajaran. Makin banyak siswa yang terlibat aktif dalam proses pembelajaran, daya serapsiswa terhadap materi dan daya ingat terhadap materi yang telah dipelajari semakin meningkat. Selanjutnya guru dalam meningkatkan kualitas mengajarnya, harus mampu merencanakan program pengajaran dan mampu melakukannya dalam proses belajar mengajar.

Cukup banyak para ahli yang merumuskan pengertian belajar. Slameto (1995) merumuskan belajar sebagai suau proses usaha yang dilakukan individu untuk memperoleh perubahan tingkah laku secara keselurruhan sebagai hasil pengalaman individu dalam interaksi dengan lingkungannya . sementara Winkel (1989) mendefinisikan belajar sebagai suatu proses kegiatan mental pada diri seseorang yang brelangsung dalam interaksi aktif individu dengan lingkungannya, sehingga menghasilkan perubahan yang relative menetap/ bertahan didalam kemampua ranah kognitif, afektif, psikomotorik.

Menurut Hudojo (1988), seseorang dikatakan belajar bila dapat diasumsikan dalam diri orang iti terjadi suatu proses kegiatan yang mengakibatkan suattu perubahan tingkah laku. Perubahan tingkah laku itu dapat diamati dan berlaku dalam kurun waktu relative lama. Perubahan tingkah laku dalam kurun waktu relative lama disertai usaha orang tersebut, sehingga orang itu dari tidak mampu mengerjakan sesuatu menjadi mampu mengerkajakannya. Tanpa usaha, walaupun terjadi perubahan tingkah laku, bukanlah belajar. Kegiatan dan usaha untuk mencapai perubahan tingkah laku itu sendiri merupakan hasil belajar.

\section{Pengertian dan Perkembangan Belajar Peserta Didik}

Peserta didik dalam arti luas adalah setiap orang yang terkait dengan proses pendidikan sepanjang hayat, sedangkan dalam arti sempit adalah setiap siswa yang belajar disekolah (Sinolungan, 1997). Departemen Pendidikan Nasional (2003) menegaskan bahwa, peserta didik adalah anggota masyarakat yang berusaha mengembangkan dirinya melalui jalur, jenjang dan jenis pendidikan. Peserta didik usia SD/ MI adalah semua anak yang berada pada rentang $6-12 / 13$ tahun yang sedang dalam jenjang pendidikan $\mathrm{SD} / \mathrm{MI}$.

Peserta didik merupakan subyek yang menjadi focus utama dalam penyelenggaraan pendidikan dan pembelajaran. Sebagai guru SD perlu memperhatikan bahwa pemahaman dan perlakuan terhadap peserta didik sebagai suatu totalitas atau kesatuan. Menurut Semiawan (1999), konsep peserta didik sebagai suatu totalitasssekurangnya mengandung arti 3 (tiga) pengertian yang mencakup pertama, peserta didik adalah makhluk hidup (organism) yang merupakan suatu kesatuan dari keseluruhan aspek yang terdapat dalam dirinya. Aspek fisik dan psikis tersebut terdapat dalam diri peserta didik sebagai individu yang berate tidak dapat terpisahkan antara suatu bagian dengan bagian yang lainnya. Kedua, keseluruhan aspek fisik dan psikis tersebut memiliki hubungan yang saling terjalin satu sama lain. Jika salah satu aspek mengalami gangguan misalnya sakit gigi (aspek fisik), maka emosinya juga terganngu (rewel, cepat marah, dll). Ketiga, peserta didik usia SD/ MI berbeda dari orang dewasa bukan sekedar secara fisik, tetapi juga keseluruhan . anak bukanlah minatur orang dewasa, tetapi anak adalah anak yang dalam keseluruhan aspek dirinya berbeda dengan orang dewasa. Disamping itu pula karakteristik anak yang lain juga berbeda, baik ditinjau dari aspek kognitif maupun dari aspke psikomotorik. 
Dengan mengetahui adanya perbedaan individu, maka seorang guru dikelas tidak dapat berharap semua anak pada usia tertentu akan memiliki kemampuan perkembangan yang sama. Pendidikan anak harus bersifat perseorangan, maksudnya pendidikan dirancang dan dilaksanakan dengan memperhatikan kondisi, bakat dan kemampuan serta kelemahan setiap individu anak.

Para pendidik member sebutan anak usia sekolah dasar, karena pada rentang usia ini (6-12 tahun) anak bersekolah diSekolah Dasar (SD). Disekolah dasar, anak diharapkan memperoleh dasar-dasar penegtahuan dan keterampilan yang dianggap penting untuk keberhasilan melanjutkan studi dan penyesuaian diri dalam kehidupannya kelak.

\section{Hakikat Keaktifan Siswa dalam Proses Pembelajaran}

Dalam Kamus Besar Bahasa Indonesia (1997), kaata keaktifan atau aktivitas diartikan sebagai kegiatan atau kesibukan. Kadi aktivitas atau keaktifan siswa dalam pembelajaran dapat dijabarkan sebagai bentuk kegiatan atau kesibukan fisik serta daya fikir atau intelektual siswa selama berlangsung kegiatn pembelajaran. Berkaitan dengan pengertian keaktifan siswa, dalam konsep belajar aktif, pengetahuan merupakan pengalaman pribadi yang diorganisasikan dan dibangun melalui proses belajar, bukan merupakan pemindahan pengetahuan yang dimiliki guru kepada anak didiknya.

Menurut Piaget ada 4 prinsip belajar aktif, yaitu (1) siswa harus membangun pengetahuannya sendiri sehingga bermakna, (2) cara belajar yang paling baik adalah jika mereka aktif dan berinteraksi dengan objek yang konkrit, (3) belajar harus berpusat pada siswa dan bersifat pribadi, (4) interaksi social dan kerja sama harus diberi peranan penting didalam kelas. Ini berarti didalam proses belajar mengajar siswalah yang harus membangun pengetahuannya sendiri, dan guru berperan untuk menciptakan kondisi yang kondusif serta mendukung terciptanya pembelajaran yang bermakna.

Siswa harus mengalami sendiri dan berinteraksi langsung dengan objek yang nyata, sebab dengan mengalaminya sendiri siswa memperoleh pengetahuan, pemahaman dan keterampilan serta perilaku lainya, termasuk sikap dan nilai. Hal ini bukan berarti guru harus pasif atau tidak aktif lagi dalam pembelajaran, tetapi guru berperan sebagai pembimbing dan fasilitator agar siswa menjadi lebih aktif dalam belajar.

Selanjutnya Herman Hudoyo (dalam Rias, 2005) mengklasifikan aktifitas belajar atau yang menurutnya disebut aktivitas intelektual siswa, seperti pada uraian dibawah ini, menguji, mengungkapkan, membuktikan, mengaplikasikan masalah, menyelesaikan masalah, mengkomunikasikan. Aktivitas ini berupa pertukaran informasi diantara siswa dengan menggunakan symbol yang sama. Para siswa harus mendapat kesempatan untuk menyetakan gagasan matematikanya secara verbal dan tertulis, mengkomprehensikan dan menginterprestasikan gagasan-gagasan yang dinyatakan oleh siswa lain.

\section{Prestasi Belajar}

Prestasi belajar yang dimaksudkan dalam penelitian ini, adalah hasil belajar yang diperoleh dari kegiatan belajar mengajar. Dengan demikian, jika tujuan pembelajarn dipandang sebagai suatu harapan yang akn diperoleh siswa setelah mengikuti kegiatan belajar mengajar, maka prestasi belajar dapat dijadikan sebagai ukuran seberapa jauh tujuan belajar telah tercapai, maka penggolongan hasil belajar dapat pula didasrkan pada penggolongan tujuan belajar

Dari uraian diatas menunjukkan bahwa prestasi belajar siswa dapat diartikan sebagai perolehan siswa setelah menjalani kegiatn belajar yang ditandai dengan nilai. Penilaian dalam penelitiaan ini dilakukan dalam bentuk tes uraian. Prestasi belajar yang diperoleh menggambarkan kemampuan siswa dalam memmahami materi yang telah mereka pelajari sebelumnya.

\section{Model Pembelajaran Kooperatif Tipe STAD}

Pembelajaran kooperatif merupakan strategi pembelajaran yang mengutamakan adanya kerja sama antar siswa dalam kelompok untuk mencapai tujuan pembelajaran. Para siswa dibagi dalam kelompok- kelompok kecil dan diarahkan untuk mempelajari materi pelajaran yang telah 
ditentukan. Tujuan dibentuknya kelompok kooperatif adalah untuk memberikan kesempatan kepada siswa agar dapat terlibat secara aktif dalam proses berpikir dan dalam kegiatan-kegiatan belajar. Dalam hal ini sebagian besar aktivitas pembelajarn berpusat pada siswa (Student Centered), yakni mempelajari materi pelajaran serta melaksanakan diskusi untuk memecahkan masalah.

Model pembelajaran kooperatif memiliki cirri-ciri antara lain: (1) siswa bekerja dalam kelompok secara kooperatif untuk menuntaskan materi belajarnya, (2) kelompok dibentuk dari siswa yang memiliki kemampuan tinggi, sedang dan rendah, (3) bilamana mungkin, anggota kelompok berasal dari tras, budaya, suku, jenis kelamin berbeda-beda, dan (4) penghargaan lebih berorientasi pada kelompok daripada individu. Model pembelajaran kooperatif tipe STAD merupakan pendekatan pembelajaran koperatif yang paling sederhana . model ini menekankan pada struktur-struktur khusus yang dirancang untuk mempengarui pola-pola interaksi siswa dan bertujuan untuk meningkatkan penguasaan isi akademik.

Menurut Slavin (1995) dalam pembelajarn kooperatif siswa kan lebih mudah menemukan dan memahami konsep-konsep yang sulit apabila mereka dapat saling mendiskusikan masalahmasalah tersebut dengan temannya. Lebih lanjut, Slavin mengemukakan bahwa dalam pembelajaran kooperatif siswa bekerjasama dalam kelompok kecil saling membantu mempelajari suatu materi. Pendapat serupa diungkapkan Thompson (dalam Suardi 2005), bahwa didalam pembelajaran kooperatif siswa belajar bersama dalam kelompok-kelompok kecil yang terdiri dari empat atau lima siswa dengan kemampuan heterogen (kemampuan tinggi, sedang dan rendah),berbeda jenis kelamin, dan suku/ ras saling membantu satu sama lain. Dengan demikian, pembelajaran kooperatif akan melatih siswa menerima perbedaan pendapat dan saling membantu untuk mealakukan aktivitas tertentu dalam menyelesaikan masalah atau tugas yang dihadapinya.

Dalam pembelajarn kooperatif ,menurut Arends (2000) terdapat enam sintaks atau harapan (fase) dalam pembelajaran, yaitu: (1) menyampaikan tujuan dan memotivasi siswa, (2) menyajikan informasi, (3) mengorganisasikan siswa dalam kelompok-kelompok belajar, (4) membimbing kelompok bekerja dan belajar (diawali dengan pemberian tugas), (5) evaluasi, dan (6) memberikan penghargaan. Kegiatan guru pada setiap fase tersebut, dapat dilihat pada table berikut ini:

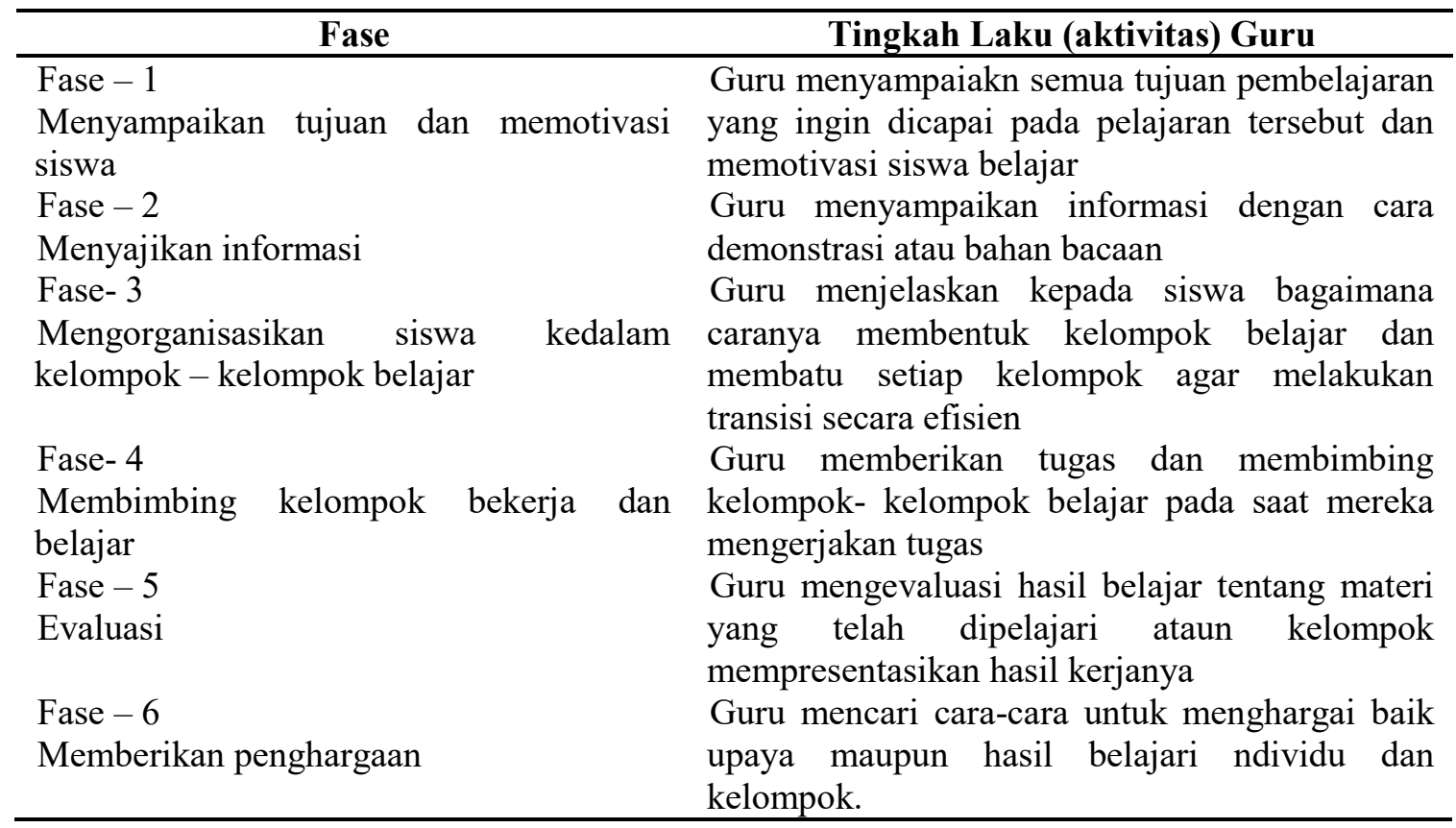

\section{Persepsi Siswa Terhadap Pembelajaran Kooperatif Tipe STAD}

Pada dasarnya kegiatan pembelajaran mwrupakan proses interaksi antara guru dan siswa. Salah satu komponen dalam proses interaksi belajar mengajar adalah bahan/ alat pelajaran dan metode pembelajaran. Dalamproses interaksi bahan/ alat dan metode yang digunakan guru dalam kegiatan pembelajaran akan member pengaruh ( stimulus), sedanbgkan siswa akan member respon 
terhadap stimulus tersebut. Dan sesuatu yang mendorong siswa untuk melakukan (memberikan respon) guna mencapai tujuan pembelajaran disebut motivasi. Dengan, demikian persepsi siswa terhadap kegiatan pembelajaran dapat dilihat dari motivasinya dalam mengikuti kegiatan pembelajaran.

Hariyadi (1994) mengatakan bahwa motivasi ditandai oleh timbulnya perasaan seperti rasa senang, tertarik, tidak puas, dan sebagainya. Dan salah satu bentuk perhatian yang erat kaitannya dengan perasaan dan kebutuhan seorang adalah minat. Sebagaimana dikatakan Hudojo (1990) bahwa salah satu bentuk motivasi antara lain adalah minat. Winkel (1984) mendefinisikan minat sebagai kecenderungan menetap dalam subyek untuk merasa tertarik pada hal tertentu dan merasa senag berkecimpung dalam bidang itu. Minat merupakan salah satu faktor yang penting dalam menunjang efektifitas pembelajaran. Karena kegiatan pembelajaran akan berjalan dengan lancar apabila ada minat, dan minat akan membangkitkan motivasi siswa akan mempengaruhi hasil belajarnya.

Pembelajaran yang paling banyakdikenal saat ini dan telah banyak digunakan dalam proses belajar adalah model pemeblajaran kooperatif .model pembelajaran kooperatif bukanlah merupakan model pembelajaran yang baru. Pembelajaran kooperatif merupakan salah satu metode yang selama ini sudah sering digunakan dalam menyusun suatu Rencana Pelaksanaan Pembelajaran . salah satu model pembelajaran yang diharapkan mampu untuk menjawab permasalahan diatas adalah diterapkannya model pembelajaran kooperatif tipe STAD (Student Teams Achiement Divisions).

Pembelajaran kooperatif tipe STAD memberikan kesempatan kepada siswa untuk meningkatkan pemahaman materi yang telah disampaikan oleh guru melalui kerjasama kelompok. Jika kelompoknya ingin mendapatkan nilai penghargaan yang terbaik maka diharapkan adanya usaha saling bantu membantu diantara teman satu kelompok dalam memahami materi yang sudah diberikan guru. STAD lebih meruoakan sebuah metode umum dalam mengelola kemandirian dan mengkaji materi selama pembelajaran berlangsung. Siswa diharapkan mampu mencapai tujuan belajar yang sudah direncanakan guru, karena pada pembelajaran ini secara langsung siswa aktif melibatkan dirinya. Model pembelajaran, ini juga dapat meningkatkan daya ingat siswa, dimana percaya diri dikalangan siswa ketika memasuki ruangan sampai dengan berakhirnya pembelajaran merupakan nuansa pembelajaran yang biasa terjadi. Dengan menggunakan model pembelajaran kooperatif tipe STAD ini, interaksi belajara mengajar akan berlangsung kesemua arah, yakni interaksi antara guru dengan siswa, dan diantara siswa dengan siswa. Bila proses pembelajaran siswa bersifat pasif dan hanya menunggu informasi yang diberikan oleh guru, ini menjadi sumber utama lemahnya mutu dan hasil belajar yang diperoleh siswa.

\section{METODOLOGI PENELITIAN}

Penelitian ini dilaksanakan dikelas IV SDN 18 Kendari.tahun pelajaran 2016/ 2017 selama 6 (enam) kali pertemuan . penelitian dilaksnakan selam dua (2) siklus, dengan sasaran perbaikan adalah peningkatan aktivitas dan prestasi belajar siswa dalam proses pembelajaran IPS diikelas IV melalui penerapan model pembelajaran kooperatif tipe STAD. Personalia peneltian diantra lain: (1) guru kelas IPS yang mengajar dikleas IV yang bertindak sebagai guru peneliti, (2) dua orang guru kelas sebagai pengfamat aktivitas siswa dan guru, (3) siswa dikelas IV yang berjumlah 40dengan perincian siswa laki-laki berjumlah 19 siswa dan siswa perempuan berjumlah 21 siswa.

Dalam hal ini guru sebagai peneliti juga sebagai yang dikenai tindakan perbaikan. Demikian pula siswa yerpengaruh oleh akibat dari perbaikan/ tindakan yang dilaksanakan oleh guru. Penelitian dilaksanakan pada semester ganjil tahun pelajaran 2015/2016 dengan rincian sebagai berikut: Tahap persiapan (Juli 2016, Tahap Implementasi Tindakan (21 Juli - 12 Agustus 2016), Tahap Penulisan Draft Laporan (September- oktober 2016), Tahap Penulisan Laporan Hasil Penelitian (Desember 2016 )

Sebagaimna yang telah dikemukakan sebelumnya bahwa penelitian ini dilaksanakan pada semester ganjil pada tahun ajaran 2015/2016 dengan dua siklus, siklus 1 dilaksanakan 3 (tiga) peretemuan dengan sasaran utama metode pembelajaran kooperatif untuk memotivasi siswa agar aktif dalam proses pembelajaran, dan melatihkan keterampilan kooperatif. Siklus II dilaksanakan 
tiga (3) kali pertemuan dengan sasaran utama melanjutkan kegiatan siklus I berdasarkan hasil refleksi dan melatihkan keterampilan kooperatif terutama keterampilan menengah dan mahir. Prosedur yang dilakukan adalah kaji tindak dengan cara mengobservasi metode guru mengajarkan secara kooperatif, mengkomunikasikan kepada guru hasil observasi, kemudian bersama-sama merumuskan tindakan yang akan digunakan pada pembelajatan selanjutnya.

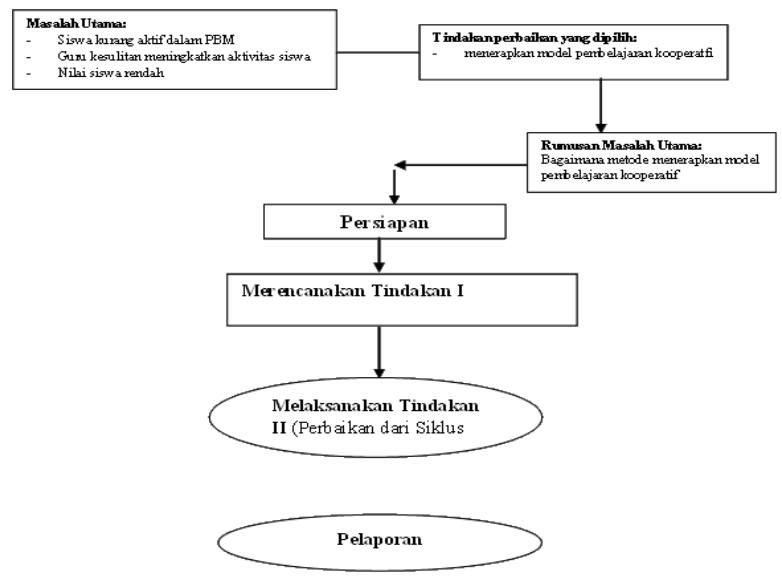

Ganbar 1: rancangan Tindakan

a. Lembar Observasi Aktivitas Guru (LOAG): Lembar observasi ini dikembangkan untuk menjaring bentuk-bentuk aktivitas guru selama pembelajaran berlangsung. Khususnya aktivitas guru pada saat siswa bekerja didalam kelompok. Komponen-komponen utama yang akan diobservasi adalah aktivitas guru dalam hal (1) memonitor perilaku siswa didalam kelompok, (2) memberikan bantuan jika diperlukan, (3) menjawab pertanyaan-pertanyaan hanya jika pertanyaan itu merupakan pertanyaan kelompok, (4) menguatkan keterampilan-keterampilan kooperatif, dan (5) memberikan ringkasan pelajaran (mengadakan negosiasi). Selain komponen utama tersebut, juga diobservasi bagaimana guru membuka dan menutup pelajaran.

b. Tes Prestasi Belajar: Tes ini dikembangkan dalam bentuk tes uraian yang diberikan siswa setiap akhir pertemuan. Rata-rata nilai yang diperoleh siswa dalam satu siklus digunakan sebagai prestasi belajar siswa dalam pembelajaran pendidikan kewarganegaraan secara kooperatif paad siklus yang bersangkutan. Tes ini dikembangkan dari materi yag diajarkan pada setiap pertemuan dengan berpedoman kepada tujuan pembelajaran yang ditetapkan didalam Rencana Pelaksanaan Pembelajarn (RPP).

c. Kuesioner Persepsi Siswa: Kuesioner yang digunakan dalam peneltian ini diadaptasi dari hasil pengemabangan Naning (2003), untuk mengukur sejauhmana persepsi siswa yang diajar dengan menggunakan model pembelajaran kooperatif. Indicator yang digunakan dalam pengembangan kuesioner adalah (1) perasaan senag atau tidak senangsiswa selama mengikuti pembelajaran, (2) menanggap baru atau tidak baru terhadap kegiatan pembelajaran. Dan (3) minat siswa mengikuti kegiatan pembelajaran.

Untuk menganalisis data dari hasil observasi, digunkan tehnik yang dikemukakan Miles dan Huberman (1992) dengan tiga tahap kegiatan, yaitu reduksidata, penyajian data, dan penarikan kesimpulan. Ketiga tahap analisis tersebut dapat digambarkan sebagai model interaktif berikut ini. 


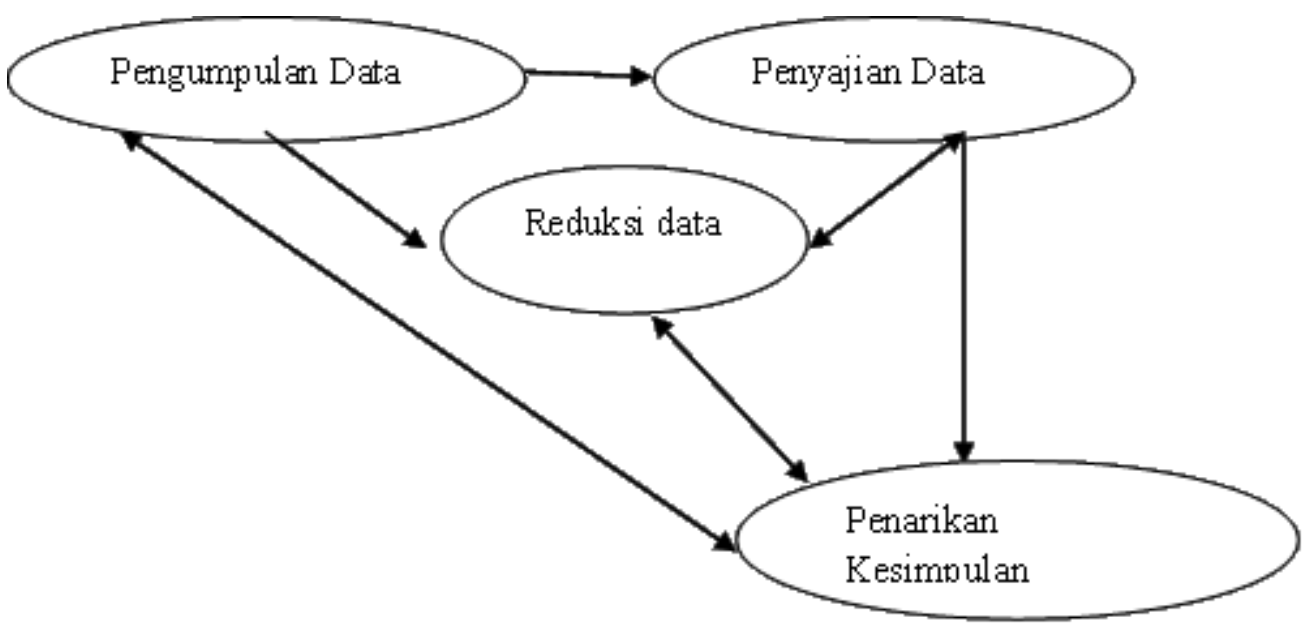

Gambar 2. Komponen Analisis Data Model Interaktif

Berdasarkan uraian diatas, analisis data yang digunakan mengikuti langkah-langkah sebagai berikut:

a. Tahap Reduksi Data: Reduksi data adalah kefiatan yang mengacu pada proses menyeleksi, memfokuskan, mengabstakkan dan menginformasikan data mentah yang diperoleh melalui observasi.

b. Tahap penyajian data: Pada tahap ini kumpulan informasi/ data yang terorganisasi dan terkategori dituliskan kembali , sehingga memungkinkan untuk menarik kesimpulan dari data tersebut. Penyajian data dalam hal ini, akan disajikan dalam bentuk matriks.

c. Tahap penarikan kesimpulan: Pada tahap ini dilakukan penarikan kesimpulan berdasarkan analisis terhadap data yang telah dikumpulkan, baik melalui observasu maupun melalui dokumentasi lainnya.

Keempat komponen analisis data seperti pada gambar 2 bersifat interaktif, dan berlangsung secara siklus. Dengan analisis ini, diharapkan dapat menjawab permasalahan utama dalam bentk penelitian. Sedangkan data dari persepsi dan prestasi belajar IPS dalam penelitian ini dianalisis dengan menggunakan statistic deskriptif.

\section{HASIL DAN PEMBAHASAN}

\section{Hasil Penelitian}

Aktivitas siswa diperoleh dari hasil pengamatan dengan menggunakan "lembar observasi aktivitas siswa" . pengamatan dilaksanakan dengan cara observer mengamati aktivitas siswa yang dilakuakn dalam setiap interval waktu dua menit, dan satu menit berikutnya digunakn untuk mencatat aktivitas siswa yang dominan dilakuakn dalam dua menit tersebut. Waktu yang diberikan siswa untuk bekerja secara kelompok untuk setiap pertemuan sekitar 45 menit (15 interval waktu). Pengamatan difokuskan pada satu kelompok (terdiri dari 4 orang siswa) yang dipilih secara acak dari 10 kelompok yang ada. Data yang diperoleh dari instrument tersebut dirangkum oleh penulis setiap akhitr pertemuan.

Aktivitas siswa yang apling banyak dilakukan adalah aktivitas dalam menyelesaikan masalah secara mandiri, dan diikuti dengan aktivitas berdiskusi. Hal ini mengindikasikan bahwa dalam pembelajarn IPS secara kooperatif, interaksi antara siswa dalam saling membantu belum dapat terlaksana dengan baik. Kebiasaan siswa untuk bekerja secara mandiri yang selama ini diterapkan guru, masih mendominasi aktivitas siswa dikelas. Namun demikian terjadinya interaksi antar siswa (walaupun frekuensinya masih kurang) mengindikasikan bahwa pembelajaran kooperatif jika dilaksanakan dalam waktu lama (tidak berarti harus kontinu), maka peluang untuk membuat siswa saling membantu dalam menyelesaikan tugas akan lebih baik, hal ini dapat dilihat 
pada siklus II bahwa frekuensi siswa saling membantu dan bertanya kepada siswa lainnya lebih banyak dibandingkan padas siklus I.

Berdasarkan hasil refleksi pada dua siklus yang dilakukan, terungkap bahwa rendahnya aktivitas siswa untuk bekerjasama dengan siswa lainnya, diakibatkan antara lain: (1) siswa selama ini terbiasa bekerja secara mandiri, (2) keterampilan kooperatif dalam bekerjasama belum dimiliki oleh siswa, (3) kebiasan kompetitif dalam belajar yang selama ini diterapkan guru membuat siswa ingin menonjol sendiri, dan (4) belum optimalnya guru melaksanakan sintaks-sintaks pada pembelajaran kooperatif.

Pada akhir pelaksanaan penelitian ini siswa diberi angket untuk mengetahui persepsi atau tanggapan siswa terhadap kegiatan pembelajaran. Dari hasil analisis respon siswa diperoleh data yang menunjukkan bahwa 57, 5\% (23 dari 40 orang) siswa menganggap cara belajar dan cara guru mengajar dalam pembelajaran kooperatif bukan merupakan hal yang baru bagi mereka.sellanjutnya $62,5 \%$ siswa menyatakan senag terhadap cara belajar dan cara menj=gajar guru. Ungkapan baru yang senang yang diberikan oleh sebagian besar siswa menunjukkan adanya respon positif siswa terhadap kegiatan pembelajarn kooperatif tipe STAD. Hal ini didukung oleh respon siswa yang menyatakn berminat mempelajari materi pembelajarn lain melalui pembelajaran kooperatif. Dengan adanya minat siswa yang besar dalam kegiatn pembelajaran akan berpengaruh kepada peningkatan motivasi belajar siswa dan pada akhirnya akan berpengaruh secara signifikan terhadap prestasi belajar siswa.

\section{Pembahasan}

Dari hasil refleksi selama proses pembelajaran tampak beberapa alasan yang mendasari menreka menyatakan senang dan berminat belajar pada mata pelajaran IPS dengan menggunakan pembelajaran kooperatif. Diantarnya, belajar melalui kelompok menjadikan konsep yang dipelajari lebih mudah didiskusikan dengan teman kelompoknya, sehingga cara berpikir dengan kemampuan yang relatif sama. Selanjutnya ada pula sebagian siswa memberikan alas an bahwa cara guru membimbing dengan berada disamping siswa yang membutuhkan bimbingan, membuat siswa meraas puas dan senag serta merasa diperhatikan. Sehingga anak menjadi termptivasi belajarnya, dan ia akan berusaha untuk mencapai keberhasilan selanjutnya, hal ini didukung hasil penelitian yang dilakukan Goleman dan kawan-kawan dalam Suradi (2005), bahwa emosi memegang peranan penting dalam proses belajar.

Hasil deskripsi tentang penguasaan siswa, menunjukkan bahwa pembelajaran kooperatif efektif dalm pencapaian tingkat penguasaan belajar siswa. Hal ini dilihat dari tingkat penguasaan (rata-rata penguasaan) yang diperoleh siswa setiap siklusnya semakin meningkat. Hal ini dapat dilihat pada table 4 berikut ini.

Table . Distribusi Frekuensi Prestasi Belajar Siswa

\begin{tabular}{|c|c|c|c|c|c|}
\hline \multirow{2}{*}{ Interval Skor } & \multirow{2}{*}{ Kategori } & \multicolumn{2}{|c|}{ Siklus I } & \multicolumn{2}{|c|}{ Siklus II } \\
\hline & & Frek. & $\%$ & Frek. & $\%$ \\
\hline $85-100$ & Sangat tinggi & 4 & $10,0 \%$ & 12 & $30,0 \%$ \\
\hline $69-84$ & Tinggi & 11 & $27,5 \%$ & 22 & $55,0 \%$ \\
\hline $53-68$ & Sedang & 10 & $25,0 \%$ & 4 & $10,0 \%$ \\
\hline 37-52 & Kurang & 13 & $32,5 \%$ & 1 & $2,5 \%$ \\
\hline $0-36$ & Sangat Kurang & 2 & $5,0 \%$ & 1 & $2,5 \%$ \\
\hline \multicolumn{2}{|c|}{ Nilai rata-rata } & \multicolumn{2}{|c|}{60,75} & \multicolumn{2}{|c|}{76,83} \\
\hline \multicolumn{2}{|c|}{ Standar Deviasi } & \multicolumn{2}{|c|}{14,81} & \multicolumn{2}{|c|}{11,55} \\
\hline \multicolumn{2}{|c|}{ Nilai Maksimum } & \multicolumn{2}{|c|}{90} & \multicolumn{2}{|c|}{90} \\
\hline \multicolumn{2}{|c|}{ Nilai Minimum } & \multicolumn{2}{|c|}{36,67} & \multicolumn{2}{|c|}{36,67} \\
\hline
\end{tabular}

Berdasrkan pada table 4 diatas, dapat dikemukakan bahwa presentase prestasi belajar siswa untuk setiap siklusnya semakin meningkta. Menurut criteria yang telah ditetapkan rata-rata penguasaan yang dicapai siswa pada akhir siklus II dalam kategori tinggi (rata-rata 76,83). Hal ini 
memberikan suatu gambaran bahwa pembelajarn kooperatif dapat meningkat penguasaan siswa dalam belajar IPS. Selain itu juga terlihat bahwa dari 40 orang siswa terdapat 34 orang (85\%) yang telah mencapai ketuntasan belajar (sesuai dengan ketentuan yang diberlakukan oleh Depdikbud bahwa siswa dikatakan tuntas belajarnya bila penguasaan siswa terhadap materi yang dipelajari minimal mencapai 65\%).

\section{KESIMPULAN}

Berdasarkan rumusan masalah danhasil ayng diperoleh dari penelitian tindakan kelas ini daapt disimpulkan sebagai berikut: Persepsi siswa terhadap pembelajaran kooperatif yang ditrapkan, pada dasrnya menaggap bahwa pembelajaran kooperatif merupakan hal baru dan mereka senag dengan cara belajar secara kooperatif. Hal ini menunjukkan adanya persepsi positif bagi siswa terhadap model pembelajarn IPS secara kooperatif, sehingga kegiatn pembelajarn akan berpengaruh kepada peningkatan motivasi belajar siswa dan pada akhirnya akan berpengaruh pula terhadap hasil belajarnya. Aktivitas siswa belajar dalam pembelajarn kooperatif mengalami peningkatan dikarenakan siswa sudah dapat menyesuaikan diri dengan standar yang disepakati dan berlaku dalam kelompoknya. Prestasi belajar IPS siswa dalam pembelajaran kooperatif, mempunyai kecenderungan semakin meningkat dari setiap siklusnya. Hal ini dapat dilihat dari nilai rata-rata yang diperoleh siswa semakin meningkat. Selain itu, frekuensi siswa yang memperoleh nilai dalam kategori baik dan sangat baik semakin meningkat. Hal ini menunjukkan bahwa pembelajaran kooperatif dapat meningkatkan prestasi belajar IPS siswa.

\section{DAFTAR PUSTAKA}

Arends, Richard I. 2000, Learning to teach. Fifth Edition, New York: MCGrawHill Companies, Inc.

Hudoyo, Herman, 1990. Strategi Belajar Mengajar Matematika. Jakarta: Depdikbud

Hariyadi, Mathias.1994. Membina Hubungan Antara Pribadi, Yogyakarta: Kanisius

Hamzah B Uno, dkk. 2004. Model Pembelajaran. Gorontalo; BMT Nurul Jannah

Kemmis, S \& McTaggart (Eds).1988. The Action Research Planner. Victoria: The Deakin University

Lungdren, Linda. 1994. Cooperative Learning In The Science Classroom. Glencoe: MacMilan? McGraw Hill

Murtadho,S, dan tambunan, G.1987. Pengajaran Matematika (MOdul UT) Karunika:Jakarta

Sudia, Muhammad, 1995. Kasulitan Siswa Dalam Mempelajari Matematika Pokok Bahasan Pangkat Rasional Di SMA Negeri 18 Surabaya (Suatu Pendekatan Kasus Dalam Upaya Merancang Metode Mangajar)Tesis S2, PPS IKIP Malang

Soedjadi, R, 2000."Pemanfaatan Realitas Dan Lingkungan Dalam Pembelajaran Matematika". Makalah disajikan pada Seminar RME, FMIPA UNESA Surabaya

Sastrawijaya, 1991. Pengembangan Program Pengajaran, Yogyakarta: universitas Gajah Mada

Sudjana, 1989. Cara Belajar Siswa Aktif Dalam Proses Belajar Mengajar. Bandung: Sinar Baru

Slavin, Robert E, 1995. Cooperative Laerning Theory, Research And Pratice, Fourth Edition, Boston: Allyn And Bacon

Suradi, 2001."Aktivitas Siswa Dalam Pembelajarn Matematika Melalui Interaksi secara Kooperatif'. Makalah Disajikan Pada Seminar hasil Observasi Penelitian Awal Disertasi, UNESA Surabaya

Suradi, 2002. "Pembelajaran Matematika Secara Kooperatif". Makalah Disajikan Pada Seminar Nasional Strategi Belajar Mengajar Matematika dalam Peningkatan kualitas Sumber daya Manusia, UNISMUH Makassar

Suradi, 2005. "Interaksi Siswa SMP dalam Pembelajaran Matematika Secara Kooperatif". Disertasi, PPS UNESA Surabaya 
E-ISSN: 2502-6674

$P-I S S N$ : 2502-6666

http://ojs.uho.ac.id/index.php/p_sejarah_uho

Utari Sumarno, 2002. Alternatif Pembelajaran Matematika Dalam Implementasi Kurikulum Berbasis Kompetensi. Makalah Disajikan Pada Seminar Pendidikan Matematika Universitas Pendidikan Indonesia, FMIPA UPI, Bandung

Winkel, WS. 1984. Psikologi Pendidikan dan Evaluasi Belajar. Jakarta;PT Gramedia Winkel,W,S. 1995. Psikologi Pengajaran. Jakarta: PT. Grasindo 